\title{
Konsumsi Nitrogen Dan Karbon Oleh Spirulina platensis Dari Kotoran Burung Puyuh Sebagai Media Kultivasi
}

\author{
Consumption of Nitrogen and Carbon by Spirulina platensis from Quail Manure as \\ Cultivation Media
}

\author{
Santi Amelia Putri ${ }^{1}$,Tatang Sopandi ${ }^{2}$ \\ 1,2Program Studi Biologi, FST, Universitas PGRI Adi Buana Surabaya \\ Email: putrititian609@gmail.com¹, tatang_sopandi@yahoo.co.id ${ }^{2}$
}

\begin{abstract}
Abstrak
Tujuan penelitian ini bertujuan untuk mengetahui tingkat konsumsi nitrogen dan karbon pada beberapa variasi konsentrasi kotoran burung puyuh sebagai media kultuvasi Spirulina platensis. Penelitian telah dilakukan pada bulan 10 April sampai 19 Juni 2020 di Laboratorium Biologi Fakultas Sains Teknologi Universitas PGRI Adi Buana Surabaya. Penelitian ini menggunakan Rancangan Acak Lengkap (RAL) dengan 4 konsentrasi kotoran burung puyuh yang masing-masing diulang 5 kali. Konsentrasi kotoran burung puyuh yang digunakan sebagai media kultivasi $S$. platensis terdiri atas 50, 100 dan $150 \mathrm{~g} / \mathrm{l}$, serta media Zarrouk sebagai control () g/l kotoran burung puyuh). Hasil penelitian menunjukkan bahwa konsentrasi kotoran burung puyuh dalam media kultivasi berpengaruh signifikan $(\mathrm{P}<0.05)$ terhadap konsumsi nitrogen dan karbon dan biomassa $S$. platensis. Konsumsi nitrogen pada kosentrasi kotoran burung puyuh 100 dan $150 \mathrm{~g} / 1$ signifikan lebih tinggi dibandingkan dengan konsumsi nitrogen pada konsentrasi $50 \mathrm{~g} / \mathrm{l}$ dan media Zarrouk. Konsumsi karbon pada konsentrasi kotoran burung puyuh $150 \mathrm{~g} / \mathrm{l}$ signifikan $(\mathrm{P}<0.05)$ dibandingkan dengan 50 dan $100 \mathrm{~g} / \mathrm{l}$ kotoran burung puyuh tetapi signifikan $(\mathrm{P}<0.05)$ lebih rendah dibandingkan konsumsi karbon pada media Zarrouk. Hasil biomassa S. platensis yang diperoleh dari media kotoran burung puyuh dengan kosentrasi $100 \mathrm{~g} / 1$ signifikan $(\mathrm{P}<0.05)$ dibandingkan 50 dan $150 \mathrm{~g} / 1$ kotoran burung puyuh tetapi signifikan lebih rendah dibandingkan biomassa yang diperoleh dari media Zarrouk. Penelitian ini menyimpulkan bahwa kotoran burung puyuh dapat dimanfaatkan sebagai sumber nitrogen dan karbon untuk kultivasi S.platensis. Konsentrasi $100 \mathrm{~g} / 1$ kotoran burung puyuh merupakan konsentrasi optimum untuk digunakan dalam media kultivasi S.platensis.
\end{abstract}

Kata kunci : S. platensis, kotoran burung puyuh, nitrogen, karbon, biomassa.

\begin{abstract}
The purpose of this study was to determine the level of nitrogen and carbon consumption in several variations in the concentration of quail manure as a cultivation medium for Spirulina platensis. The study was conducted from April 10 to June 19, 2020 at the Biology Laboratory of the Faculty of Science and Technology, Universitas PGRI Adi Buana, Surabaya. This study used a completely randomized design (CRD) with 4 concentrations of quail manures, each of which was repeated 5 times. The concentrations of quail manures used as the cultivation medium for S. platensis consisted of 50, 100 and $150 \mathrm{~g} / \mathrm{l}$, and Zarrouk's medium as control ( $0 \mathrm{~g} / \mathrm{l}$ of quail manures). The results showed that the concentration of quail manures in the cultivation medium have a significant effect ( $P$ $<0.05)$ on nitrogen and carbon consumption and $S$. platensis biomass. The nitrogen consumption at the quail manures concentrations of 100 and $150 \mathrm{~g} / \mathrm{l}$ was significantly $(P<0.05)$ higher than the nitrogen consumption at the concentration of $50 \mathrm{~g} / \mathrm{l}$ and Zarrouk media. Carbon consumption at $150 \mathrm{~g} / \mathrm{l}$ quail manures concentration was significant $(P<0.05)$ higher than 50 and $100 \mathrm{~g} / \mathrm{l}$ but significantly $(P<0.05)$ lower than carbon consumption on Zarrouk medium. The yield of $S$. platensis biomass obtained from quail manure medium with a concentration of $100 \mathrm{~g} / \mathrm{l}$ was significant $(P<0.05)$ higher than 50 and $150 \mathrm{~g} / \mathrm{l}$ but significantly $(P<0.05)$ lower than the biomass obtained from Zarrouk medium. This study concluded that quail manure can be used as a source of nitrogen and carbon for S.platensis cultivation media. The concentration of $100 \mathrm{~g} / \mathrm{l}$ of quail manure is the optimum concentration for use in S.platensis cultivation media.
\end{abstract}

Keywords: S. platensis, quail manure, nitrogen, carbon, biomass.

\section{PENDAHULUAN}

Mikroalga $S$. platensis merupakan salah satu jenis mikroalga yang telah banyak dikultivasi dan digunakan dalam berbagai bentuk industri karena memiliki banyak kandungan nutrisi seperti protein, asam lemak, vitamin, dan antioksidan yang tinggi (Danesi et al. 2011).Pemanfaatan $S$. platensis telah berkembang menjadi makanan manusia, pakan ternak dan bahan 
baku kimia untuk keperluan bidang medis, penelitian biologi, dan kosmetik (Rusyani et al. 2007). Spirulina platensis tidak hanya memiliki kapasitas untuk menghasilkan produk yang mempunyai nilai tinggi, tetapi juga memiliki kemampuan untuk berkembangbiak hanya dengan menggunakan cahaya matahari, karbon dioksida dan air laut (Suantika et al. 2009).

Nitrogen, karbon dan fosfor merupakan unsur nutrisi utama yang dibutuhkan oleh S.platensis untuk proses keberlangsungan hidup dan pertumbuhan. Unsur nitrogen merupakan suatu komponen untuk meningkatkan aktivitas metabolisme dan pembelahan sel mikroalga (Rafiqul. 2005). Kandungan nitrat yang optimum sekitar 0,9-3,5 g/l dibutuhkan untuk menunjang proses keberlangsungan hidup dan proses pertumbuhan mikroalga pada $S$. Platensis (Andersen, 2005). Nitrogen, fosfor dan karbon merupakan komponen nutrisi yang harus tersedia dalam media kultivasi S. platensis (Adhikari, 2004).

Kotoran burung puyuh masih dianggap limbah dan salah satu penyebab polusi lingkungan, karena belum banyak dimanfaatkan dan terbuang. Kotoran puyuh mengandung karbon, nitrogen, fosfor dan kalsium (Wardah dan Panjaitan, 2019). Limbah kotoran burung puyuh mengandung banyak kadar protein dalam bentuk nitrogen dan unsur hara makro maupun mikro dan sering dimafaatkan pupuk organik tanaman (Arbiatur dan Sopandi 2016). Kandungan yang terdapat nitrogen total kotoran burung puyuh sebanyak $2,86 \%$ dan nutrien lain seperti protein $21 \%$, nitrogen $0,061 \%, \mathrm{P}_{2} \mathrm{O}_{5}$ 0,209\%, dan kandungan $\mathrm{K}_{2} \mathrm{O} 3,133 \%$ (Huri dan Syafriadiman 2007).

Limbah peternakan berpotensi sebagai sumber nutrisi dalam media kultivasi S.platensis yang murah (Sopandi et al. 2020). Beberapa penelitian melaporkan bahwa $S$. platensis dapat dikultivasi dalam media yang dibuat dari kotoran burung puyuh. Kotoran burung puyuh telah digunakan sebagai pupuk dalam kultivasi Daphnia spp. dan lebih baik dibandingkan dengan kotoran ayam, sapi dan kambing
(Herman et al, 2018). Namun publikasi mengenai pemanfaatan kotoran burung puyuh sebagai media kultivasi terutama konsumsi karbon dan nitrogen oleh S.platensis belum banyak dilaporkan Penelitian bertujuan untuk mengetahui tingkat konsumsi nitrogen dan karbon pada beberapa variasi konsentrasi kotoran burung puyuh sebagai media kultuvasi S. platensis.

\section{MATERI DAN METODE PENELITIAN Waktu dan Tempat}

Peneilitian ini telah dilakukan pada tanggal 10 April sampai 19 Juni 2020 di Laboratorium Biologi Fakultas Sains Teknologi Universitas PGRI Adi Buana Surabaya.

\section{Materi Penelitian}

Alat yang digunakan diantaranya lampu Tl, Toples, Aerator, Kertas Label, Timbangan Analitik, kain saring, Pengaduk Kaca, dan Spektrofotometer. Bahan yang digunakan pada penelitian ini meliputi bibit S. platensis, Media Zarrouk, dan Kultivasi Media Kotoran Burung Puyuh.

\section{Rancangan Penelitian}

Penelitian telah dilakukan secara eksperimental menggunakan rancangan acak lengkap (RAL) dengan 4 perlakuan konsentrasi kotoran burung puyuh dalam media kultivasi S.platensis yang masingmasing diulang 6 kali. Konsentrasi kotoran burung puyuh yang digunakan dalam penelitian ini terdiri dari $0 \mathrm{~g} / \mathrm{l}$ (media Zarrouk sebagai kontrol), 50, 100 dan 150 $\mathrm{g} / \mathrm{l})$.

\section{Pembuatan media kultivasi}

Sebanyak 1500 g kotoran burung puyuh dijemur selama 6 hari di bawah sinar matahari selama 6 hari, disterilisasi dalam autoklaf selama 3 jam pada suhu $121^{\circ} \mathrm{C}$ tekanan 1 atmosfir. Kotoran puyuh steril dibagi menjadi 3 bagian dan dibuat masingmasing konsentrasi 50, 100, dan $150 \mathrm{~g} / \mathrm{l}$ dalam air distilasi. Masing-masing media kotoran ayam ditambahkan larutan $\mathrm{NaCl}$ dan $\mathrm{NaHCO}$ sampai mencapai $\mathrm{pH} 9$. 
Selanjutnya dibuat media Zarrouk sebagai kontrol. Sebanyak $250 \mathrm{ml} / 1$ bibit S.platensis ditambahkan ke dalam media. Kultivasi dilakukan selama 10 hari dengan aerasi aquarium SONIC secara terus menerus dengan intesitas cahaya lampu TL 5000 lux selama 24 jam, pada suhu $28^{\circ} \mathrm{C}-30^{\circ} \mathrm{C}$.

\section{Biomassa}

Pengamatan biomassa S.platensis pada hari ke-10 kultivasi menggunakan metode spektrofometer sesuai petunjuk (Vonshak, 1985). Setelah umur 10 hari, media kultivasi $S$. platensis dituangkan ke dalam disaring kain mikro berukuran 100 $\mu \mathrm{m}$. Hasil saringan secara berurutan dicuci 2 kali dengan air distilat, dikering anginkan selama 24 jam. Biomassa yang diperoleh dikeringkan lebih lanjut dalam pengering rak pada suhu $60^{\circ} \mathrm{C}$ selama 15 menit. Biomassa kering dalam cawan porselen ditimbang menggunakan neraca analitik. Sebanyak $1 \mathrm{~g}$ biomassa kering dilarukan dalam air distilata dan absorbansinya diukur dengan spectrometer pada panjang gelombang 680 $\mathrm{nm}$.

\section{Kandungan nitrogen}

Konsentrasi Nitrogen (NH4-N) dalam media dilakukan sebelum dan sesudah kultivasi dan ditentukan menggunakan metode American Society of Agronomy dan Soil Science Society of America (1982). Sebanyak $100 \mathrm{ml}$ media kultur diuapkan pada suhu $100^{\circ} \mathrm{C}$, selama kurang lebih 2 jam untuk mendapatkan bubuk kering. Sampel (50 mg) ditambahkan ke tabung pencernaan dan $1 \mathrm{~g}$ selenium campuran (dihaluskan 1,55 g $\mathrm{CuSO}_{4}, 96,9$ g $\mathrm{Na}_{2} \mathrm{SO}_{4}$ dan $1,55 \mathrm{~g}$ $\begin{array}{llllll}\text { selenium) dan } & 3 & \mathrm{ml} & 97 \% & \mathrm{H}_{2} \mathrm{SO}_{4}\end{array}$ ditambahkan, dicampur dan dicerna pada $350^{\circ} \mathrm{C}$ selama 4 jam untuk mendapatkan ekstrak yang tidak berwarna, didinginkan sampai suhu kamar, diencerkan hingga 50 $\mathrm{ml}$ dengan air suling, dikocok dengan kuat dan dibiarkan berdiri di malam hari. 2 ekstrak dipindahkan ke tabung reaksi gelas borosilikat baru dan $4 \mathrm{ml}$ buffer tartrat ( 50 $\mathrm{g} / \mathrm{l} \mathrm{NaOH}$ dan $\left.50 \mathrm{~g} / 1 \mathrm{KNaC}_{4} \mathrm{H}_{4} \mathrm{O}_{6}\right)$ dan larutan natrium fenat $(100 \mathrm{~g} / \mathrm{l} \mathrm{NaOH}$ dan 125 g/l fenol) berturut-turut ditambahkan, campur dan diamkan selama 10 menit. $4 \mathrm{ml}$ $\mathrm{NaOCl} 5 \%$ kemudian ditambahkan, sedangkan campuran dikocok, didiamkan selama 10 menit dan diuji menggunakan spektrofotometer pada panjang gelombang $680 \mathrm{~nm}$ dan $\left(\mathrm{NH}_{4}\right)_{2} \mathrm{SO}_{4}$ dibuat sebagai standar.

\section{Kandungan karbon}

Kosentrasi karbon dalam media kultivasi S.platensis dianalisis sebelum dan sesudah kultivasi dan ditentukan dengan metode oksidasi basah sesuai petunjuk Walkey dan Black (1965). Sebanyak $100 \mathrm{ml}$ media dievaporasi pada suhu $100^{\circ} \mathrm{C}$ selama 2 jam untuk memperoleh serbuk. Sebanayk $0.5 \mathrm{~g}$ serbuk sampel diabukan dimasukan dalam labu Erlenmeyer yang berisi $50 \mathrm{ml}$ aqaudest dan diteteskan $5 \mathrm{ml}$ larutan iodine. Setelah dihomogenkan dilakukan uji ioden dengan mengukur absorbansinya spektrofotometer pada panjang gelombang $680 \mathrm{~nm}$.

\section{Analisis Data}

Data hasil pengamatan pertumbuhan S. platensis, kadar nitrogen dan karbon dianalisis statistika menggunakan analisis varian satu arah selang kepercayaan 0,05. Uji beda nyata jujur pada selang kepercayaan 0,05 digunakan untuk mengetahui letak perbedaan antara perlakuan.

\section{HASIL DAN PEMBAHASAN Nitrogen dalam media kultivasi}

Hasil analisis kadar nitrogen dalam media sebelum dan sesudah dilakukan kultivasi disajikan pada Gambar 1. Kadar nitrogen sebelum kultivasi tertinggi terdapat pada media dengan konsentrasi kotoran burung puyuh $150 \mathrm{~g} / \mathrm{l}$ sebesar yaitu $0.09 \pm 0.08 \%$ yang signifikan $(\mathrm{P}<0.05)$ lebih tinggi dibandingkan dengan kadar nitrogen pada konsentrasi kotoran burung puyuh 50 dan $100 \mathrm{~g} / 1$ serta media Zarrouk. Kadar nitrogen setelah kultivasi tertinggi diperoleh dari media kotoran burung puyuh $150 \mathrm{~g} / 1$ $(0.07 \pm 0.03)$ yang signifikan $(\mathrm{P}<0.05)$ lebih 
tinggi dibandingkan 50 dan $100 \mathrm{~g} / 1$ kotoran burung puyuh serta media Zarrouk. Konsumsi nitrogen (Gambar 2) tertinggi diperoleh dari media dengan konsentrasi kotoran burung puyuh 100 dan $50 \mathrm{~g} / 1$ yang signifikan $\quad(\mathrm{P}<0,05) \quad$ lebih tinggi dibandingkan konsentrasi kotoran burung puyuh $50 \mathrm{~g} / 1$ dan media Zarrouk.

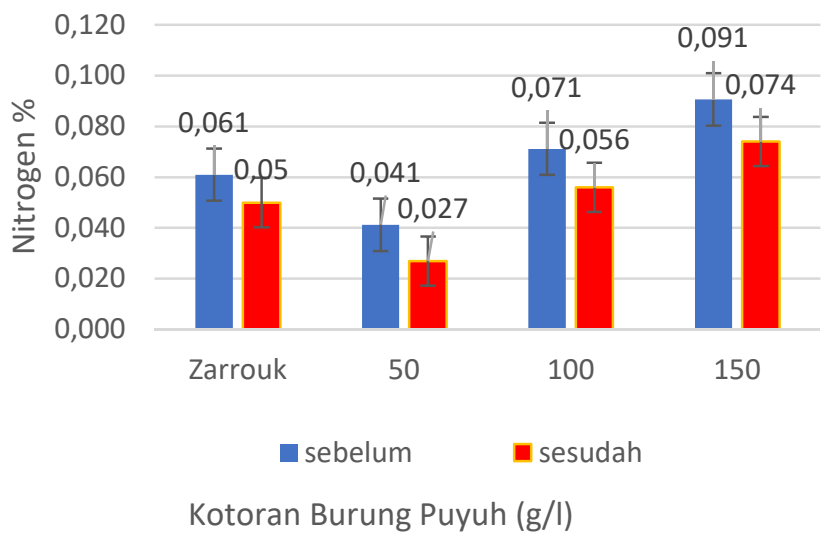

Gambar 1. Kandungan nitrogen pada media kotoran burung puyuh dan media Zarrouk sebelum dan sesudah kultivasi $S$. platensis.

Hasil analisis kadar nitrogen dalam media kotoran burung puyuh sebelum dan sesudah kultivasi mengindikasikan bahwa S.platensi dapat memanfaatkan unsur nitrogen yang tersedia dalam kotoran burung puyuh. Unsur nitrogen berperan penting untuk proses pertumbuhan mikroalga dan unsur dasar yang dapat memproses pembentukan sel DNA, RNA dan enzim. Unsur nitrogen dalam keadaan lebih atau rendah pada mikroalga dapat menghambat laju pertumbuhan pada sel mikroalga. Penambahan unsur nitrogen yang sesuai serta factor lingkungan yang mendukung dapat menghasilkan proses fotosintesis yang optimal pada mikroalga sehingga dapat meningkatkan laju pertumbuhan mikroalga dan menghasilkan kosentrasi biomassa yang tinggii (Backer,1994). Menurut Oh-Hama dan Miyachi (1998) bentuk dari senyawa nitrogen yang lebih disukai oleh mikroalga adalah ammonium $\mathrm{NH}_{4}{ }^{+}$karena terdapat proses transportasi dan asimilasi ion ammonium oleh sel fitoplankton membutuhkan energy yang lebih sedikit dibandingkan dengan transportasi dan asimilasi ion nitrat $\left(\mathrm{NH}_{3}\right)$, Menurut Effendi (2003) unsur nitrit merupakan bentuk peralihan ammonium dan nitrit dan antara nitrat dan gas nitrogen. Mikroalga lebih suka ammonium sebagai sumber nitrogen. Penghambatan dari pengambilan unsur nitrat dapat diubungkan dengan sistem enzim inaktif eleh ammonia atau produk yang telah dihasilkan oleh asimilasi ammonia. Ammonia tidak memiliki enzim reductase untuk asimilasi tetapi nilai dari unsur nitratt dapat mereduksi ammonia sebelum dapat diasimilasi oleh mikroalga. Reduksi nitrat menjadi ammonia melalui dua enzimatik yang sifatnya bebas. Pertama unsur nitrat menjadi nitrit dikatalisis oleh $\mathrm{NADH}_{2}$ - nitrat di reductase dan yang kedua reduksi dari nitrat menjadi ammonia dikatalisis ferredoxin-nitrat reductase (Munafi, 2011). 


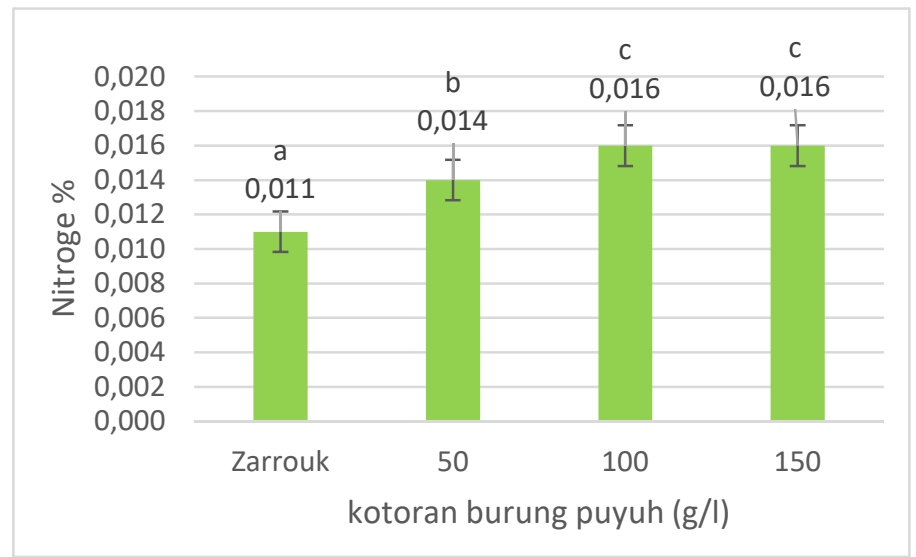

Gambar 2. Konsumsi nitrogen oleh S. platensis pada media Zarrouk dan kotoran burung puyuh.

Nitrogen pada media kultivasi sianobakteria digunakan secara primer untuk pertumbuhan sel dan sisanya disimpan sebagai komponen bahan organik. (Rodrigues et al.2010). Kandungan pada Ntotal pada kotoran burung puyuh yaitu sebanyak $2,86 \%$ dan nutrient lain yaitu protein sebesar $21 \%$, nitrogen $0,061 \%$, $\mathrm{P}_{2} \mathrm{O}_{5} 0,209 \%$, dan kandungan $\mathrm{K}_{2} \mathrm{O}$ sebesar $3,133 \%$ (Huri dan Syafriadiman, 2007). Nitrogen merupakan unsur yang berpengaruh terhadap produktivitas mikroalga secara langsung terhadap biomassa yang dihasilkan. Selain sumber nitrogen kondisi luar juga mempengaruhi seperti $\mathrm{pH}$, temperature dan cahaya. Konsumsi nitrogen pada media $S$. platensis dengan kosentrasi $100 \mathrm{~g} / \mathrm{l}$ merupakan konsentrasi optimum.

\section{Karbon dalam media kultivasi}

Hasil analisis kadar karbon sebelum dan sesudah kultivasi S.platensis disajikan pada Gambar 3. Kadar karbon sebelum kultivasi S.platensis tertinggi dari media dengan konsentrasi kotoran burung puyuh $150 \mathrm{~g} / \mathrm{l}$ yang signifikan $(\mathrm{P}<0.05)$ lebih tinggi dibandingkan konsentrasi kotoran burung puyuh 50 dan $100 \mathrm{~g} / 1$ serta media Zarrouk. Kadar karbon setelah kultivasi S.platensis tertinggi diperoleh dari media dengan konsentrasi kotoran burung puyuh $150 \mathrm{~g} / 1$ yang signifikan $(\mathrm{P}<0,05)$ lebih tinggi dibandingkan dengan konsentrasi kotoran burung puyuh 50 dan $100 \mathrm{~g} / 1$ serta media Zarrouk. Konsumsi karbon (Gambar 4) tertinggi diperoleh dari media Zarrouk yang signifikan $(\mathrm{P}<0.05)$ lebih tinggi disbanding semua media kotoran burung puyuh. Konsumsi karbon tertinggi di antara media kotoran burung puyuh diperoleh pada media media kotoran burung puyuh $150 \mathrm{~g} / 1$ yang signifikan $(\mathrm{P}<0,05) \quad$ lebih tinggi dibandingkan dengan $50 \mathrm{~g} / \mathrm{l}$, tetapi tidak berbeda signifikan $(\mathrm{P}>0,05)$ dibandingkan dengan konsentrasi kotoran burung puyuh $100 \mathrm{~g} / 1$. 


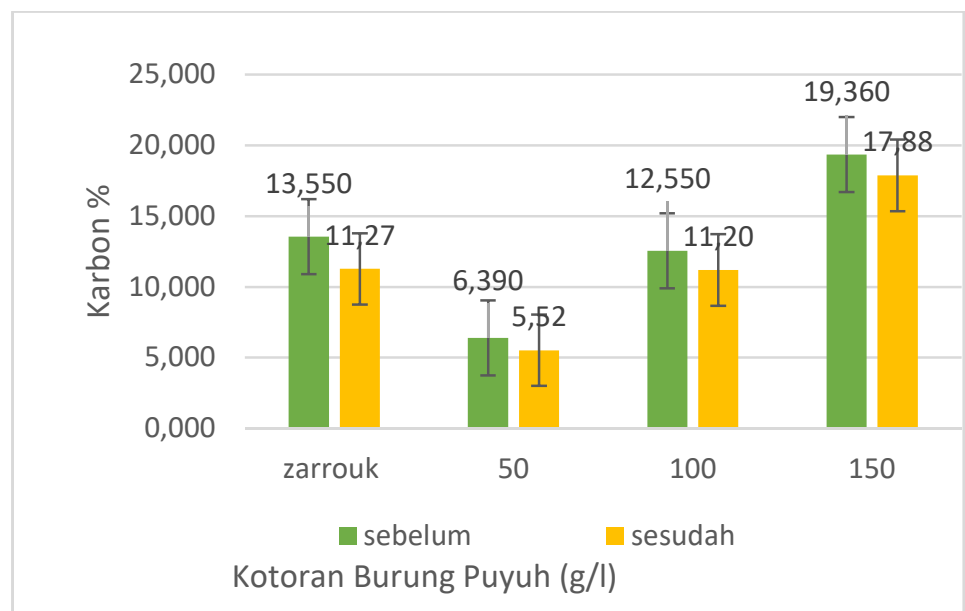

Gambar 3. Kadar karbon pada media kotoran burung puyuh dan media Zarrouk sebelum dan sesudah dikultivasi $S$. platensis.

Hasil analisis karbon mengindikasikan bahwa S.platensis dapat memanfaatkan karbon yang tersedia dalam kotoran burung puyuh. Konsentrasi $100 \mathrm{~g} / 1$ kotoran burung puyuh dalam media merupakan konsentrasi optimum untuk kultivasi S.platensis. Karbon merupakan unsur yang berpengaruh terhadap produktivitas mikroalga secara langsung terhadap biomassa yang dihasilkan. Proses fotosintesis merupakan proses pengambilan $\mathrm{CO}_{2}$ yang terlarut di dalam air dan mengakibatan penurunan pada $\mathrm{CO}_{2}$ yang terlarut dalam air. Penurunan $\mathrm{CO}_{2}$ akan mengakibatkan peningkatan $\mathrm{pH}$. Dalam keadaan basa ion bikarbonat akan membentuk ion karbonat yang melepaskan ion hidrogen yang bersifat asam sehingga keadaan menjadi netral . sebaliknya dalam keadaan terlalu asam, ion karbonat akan mengalami hidrolisa menjadi ion bikarbonat dan melepaskan ion hydrogen oksida yang bersifat basa, sehingga keadaan netral kembali (Lavens dan Sorgelos, 1996). $S$. platensis merupakan mikroalga cyanobacteria, pada kondisi lingkungan ruang netral $\mathrm{CO}_{2}$ berada dalam bentuk bebas sehingga dapat berdifusi dengan sangat muda dalam bentuk sel mikroalga. Hal ini dapat menyebabkan $\mathrm{CO}_{2}$ sebagai sumber karbon bagi proses metabolism yang dapat berlangsung secara cepat dan dapat mendorong peningkatan kepadatan mikroalga $S$. platensis (Wimas, 2012).

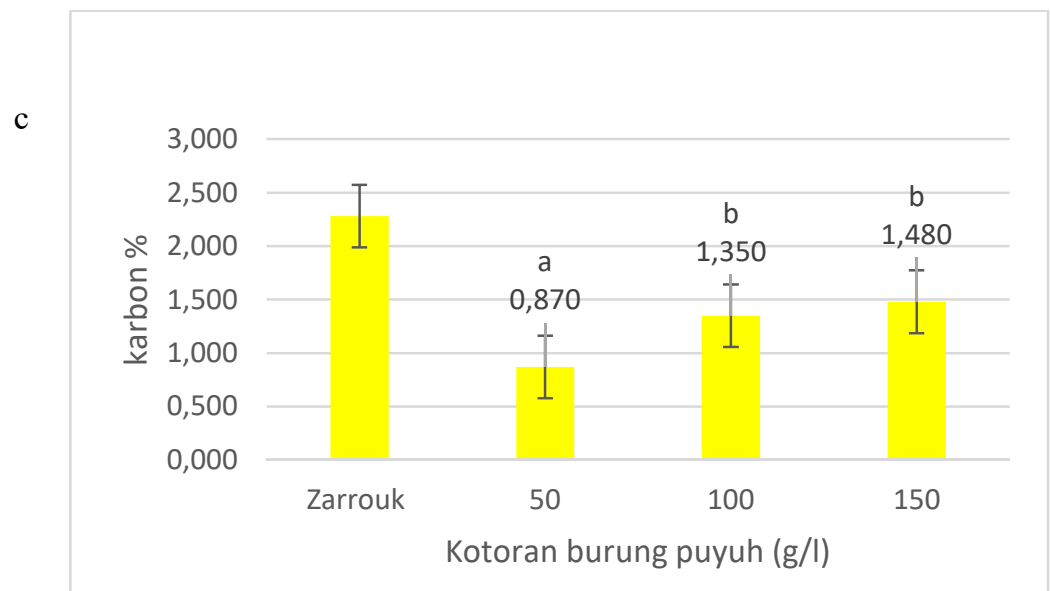

Gambar 4. Konsumsi Karbon oleh S. platensis pada media Zarrouk dan kotoran burung puyuh. 


\section{Biomassa Spirulina platensis}

Hasil penelitian memperlihatkan biomassa $S$. platensis (Gambar 5) tertinggi diperoleh dari media Zarrouk yang signifikan $(\mathrm{P}<0,05) \quad$ lebih tinggi dibandingkan dengan media kotoran burung puyuh dengan konsentrasi 50, 100 dan 150 $\mathrm{g} / \mathrm{l}$. Biomassa S.platensis tertinggi di antara media kotoran burung puyuh ditemukan pada media kotoran burung puyuh dengan konsentrasi $100 \mathrm{~g} / \mathrm{l}$ yang signifikan $(\mathrm{P}<0,05)$ dibandingkan dengan 50 dan $150 \mathrm{~g} / \mathrm{l}$.

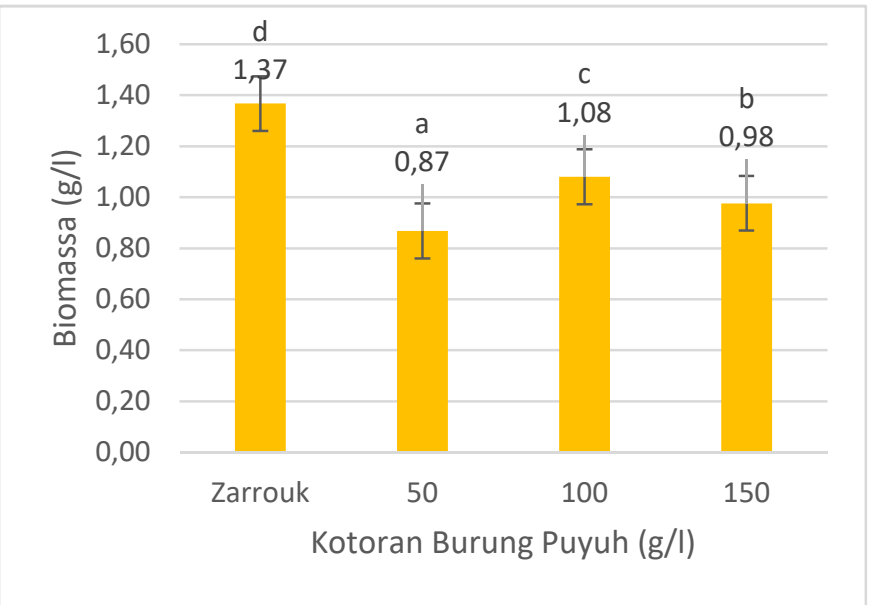

Gambar 5. Biomassa S. platensis yang dikultivasi pada media kotoran burung puyuh dan Zarrouk.

Biomassa yang dihasilkan dari panen $S$. platensis berkaitan dengan jumlah kepadatan sel yang telah dihasilkan. Berdasarkan hasil kepadatan sel S. platensis nilai meningkat setelah dibiakan selama 10 hari. hal ini terlihat pada saat uji spektrofotometer. Nilai kepadatan sel meningkat seiring ditambahkan media kultivasi kotoran burung puyuh. Kandungan nitrogen dan Karbon yang terdapat pada kultivasi media kotoran burung puyuh dapat meningkatkan biomassa $S$. platensis. Kandungan nitrat dari sumber nitrogen yang mendukung pertumbuhan sel mikroalga dan menyebabkan hasil biomassa tinggi.

Hasil penelitian ini mengindikasikan bahwa kotoran burung puyuh tidak dapat sepenuhnya menggantikan media Zarrouk untuk kultivasi S.platensis. Namun dengan melakukan optimalisasi kondisi kultivasi dan pengkayaan nutrisi, kotoran burung puyuh berpotensi untuk digunakan sebgai media kultivasi S.platensi menggantikan media Zarrouk. Produksi biomassa serta kandungan nutrisi sangat tergantung pada ketersediaan nutrient dalam media kultur.
Menurut Raoof et al (2005) yang menyatakan bahwa sumber unsur nitrogen yang terdapat pada bahan kimia $\mathrm{NaNO}_{3}$ dan $\mathrm{KNO}_{3}$ merupakan unsur yang paling penting bagi mikroalga sebagai proses pertumbuhan sel $S$. platensis. Unsur nitrogen merupakan nutrient yang dibutuhkan paling banyak untuk pertumbuhan fitoplanton. Dan unsur nitrogen yang dibutuhkan oleh $S$. platensis biasanya didapatkan dalam bentuk unsur nitrat $\left(\mathrm{NO}_{3}\right)$.

Kepadatan populasi awal mikroalga $S$. platensis yang berbeda dapat menghasilkan kurva pertumbuhan populasi yang berbeda pula namun tidak mempengaruhi hasil kurva pertumbuhan biomassa yang berbeda. Hal ini dapat menunjukkan bahwa dari pemberian perlakuan pada kepdatan inoculum yang berbeda tidak mempengaruhi kurva hasil pertumbuhan biomassa tetapi hanya pada pertumbuhan populasi saja. Diduga karena sel $S$. platensis menggunakan nutrisis pada lingkungan yang lebih cenderung untuk bereproduksi yaitu dengan cara pembelahan diri namun tidak dioptimalkan untuk pertumbyhan biomassa (Prayata, 2013). 


\section{SIMPULAN DAN SARAN Simpulan}

Penelitian ini menyimpulkan bahwa kotoran burung puyuh dapat digunakan sebagai sumber nitrogen dan karbon media kultivasi S. platensis. Konsentrasi $100 \mathrm{~g} / \mathrm{l}$ kotoran burung puyuh merupakan konsentrasi optimum untuk kultivasi S.platensis.

\section{Saran}

Penelitian ini menyarankan untuk menggunakan kotoran burung puyuh sebagai media kultivasi $S$. platensis dengan kosentrasi $100 \mathrm{~g} / \mathrm{l}$. Penelitian ini lebih lanjut perlu dilakukan untuk optimalisasi kondisi kultivasi dari pengaruh lingkungan seperti aerasi, dan cahaya.

\section{DAFTAR PUSTAKA}

American Society of Agronomy and Soil Science Society of America (1982) Methods of Soil Analysis, 2nd edn, Part 2. In Chemical and Microbiological

Properties eds. A.L. $\quad$ Page, R.H. Miller and D.R.Keeney pp. 649- 670.

Madison, WI: American Society of Agronomy and Soil Science Society of America.

Andhikari. 2004. Fertilization,Soil and Water Quality Management in Small Scale Pond: Fertilization Requirements and Soil Properties: 3 Hal.

Andersen, R.A. (2005). Algal culturing techniques. Academic Press. Elsevier Science. San Diego. California. U.S.A. 596 p.

Arbiatur, F dan Sopandi, T. 2016. Pengaruh pemberian tepung kiambang (Salvinia molesta) terhadap produksi telur dan efisiensi pakan pakan puyuh Cortunix-cortunix japonica). Stigma Journal of science 9(2):15-19.

Beacker Gary S (1993) Hunian Capital. Atheotized and Empirical Analysis with Special Reference to Education. Chicago and London, The University of
Chicago Press.

Danesi,E.D.G.,Rangel-Yagui,C.O.,Sato,S and Carvalho, J.C.M.(2011). Growth and Content of Spirulina Platensis Biomass Chlophyll Cultivated at Different Values of Light Intensity and Temperature Using Different Nitrogen Sources, Brazilian Journal of Microbiology 42(1),362-373.

Effendi, H.2003. Telaah Kualitas Air Bagi Pengelola Sumber Daya dan Lingkungan Perairan. Yogyakarta: Kasnisius.

Herman, H. Y, Andriani. A, Sahidin. T, Hidayat. And T, Herawati. 2018. Culture of Daphnia sp. (crustaceancladocera): the effect of manure variation on the growth, natality, and mortality. IOP Conf. Series : Earth and Enviromental science, 137.

Huri, E. Dan Syafriadiman. 2007. Jenis dan Kelimpahan Zooplankton dengan Pemberian Dosis Puuk Kotoran Burung Puyuh yang Berbeda. Berkala Perikana Terubuk 35(1): 1-19.

Lavens, P. and Sorgeloos, P. (1996) Manual on the Production and Use of Live Food for Aquaculture. FAO Fisheries Technical Paper No. 361, Rome. http://www.fao.org/docrep/003/W3732 E/W3732E00.HTM

Prayata, H. D.,S. Waspodo, Ayu Adhita D., (2013). Pengaruh Kepadatan Inokulum Terhadap Pertumbuhan Populasi dan Biomassa Spirulina sp Rafiqul IM, Jalal KCA, Alam MZ.2005. Environmental Factors for Optimisation of Spirulina Biomass in Labotratory Culture. Journal of Biotechnology 4(1): 19-22.

Ramaiyulis dan Nilawati., 2009. Buku Ajar Bahan Protein dan Formulasi Ransum. Politeknik Pertanian Negeri Payakumbuh.

Raoof, B. Kaushik, B.D. Prasanna, R. 2005. Formulation of a low-cost medium production of spirulina, Divison of Microbiology, Indian Agricultural formass Research Institute, New Delhi 110 012, India $>$ Centre for Conservation and Utilization of Blue- 
Green Algae, Indian Cagricultural Research Institute, New Delhi, 110012 , India,pp. 1 - 5.

Rusyani, E., Sapta A. I. M, Lydia E., 2007. Budidaya Fitoplankton Skala Laboratorium dalam Budidaya Fitoplankton dan Zooplankton. Balai Budidaya Laut Lampung. Direktorat Jendral Perikanan Budidaya. Departemen Kelautan dan Perikanan: 9. Lampung. Hal.48-59.

Suantika, G.2009. Efektivitas teknik kultur menggunakan sistem kultur statis, semikontiyu dan kontiyu terhadap produktivitas dan kualitas kultur Spirulina sp. J.Matematika dan Sains 14(2):1-9.

Sopandi, T, Rohmah, and Agustina, S.A.T. 2020. Biomass and nutrient composition of Spirulina platensis grown in goat manure media. Asian J Agric \& Biol. 2020;8(2):158-167.

Vonshak, A. and A Richmond. 1988. Mass Production of the Blue-green Algae Spirulina: an Overview. The Microalga Biotechnology Laboratory. The Jacob Blaustein Institute for Desert Research. Israel.

Walkey,C. and Black,C.A. (1965). Organic carbon. In Methods of soil analysis ed. C.A.Black pp. 1372-1375. Madison, WI: American Society of Agronomy.

Wardah dan Panjaitan, T.W.S. 2019. Substitusi Butiran Kering Destilat Pada Formulasi Pakan Puyuh Terhadap Kandungan Kimia Feses. Stigma 12 (2): 54-65. 